\title{
Identification of the complete coding CDNAs and expression analysis of B4GALT1, LALBA, ST3GAL5, ST6GAL1 in the colostrum and milk of the Garganica and Maltese goat breeds to reveal possible implications for oligosaccharide biosynthesis
}

\author{
Alessandra Crisà ${ }^{1,2^{*}}$ (D), Salvatore Claps ${ }^{1,2}$, Bianca Moioli ${ }^{1,2}$ and Cinzia Marchitelli, ${ }^{1,2}$
}

\begin{abstract}
Background: Milk sialylated oligosaccharides (SOS) play crucial roles in many biological processes. The most abundant free SOS in goat's milk are 3'sialyllactose (3'-SL), 6'sialyllactose (6'-SL) and disialyllactose (DSL). The production of these molecules is determined genetically by the expression of glycosyltransferases and by the availability of nucleotide sugar substrates, but the precise mechanisms regulating the differential patterns of milk oligosaccharides are not known. We aimed to identify the complete cDNAs of candidate genes implicated in SOS biosynthesis (B4GALT1, LALBA, ST3GAL5, ST6GAL1) and to analyse their expression during lactation in the Garganica and Maltese goat breeds. Moreover, we analysed the colostrum and milk contents of 3'-SL, 6'-SL and disialyllactose (DSL) and the possible correlations between expressed genes and SOS.

Results: We identified the complete coding CDNAs of B4GALT1 (HQ700335.1), ST3GAL5 (KF055858.2), and ST6GAL1 (HQ709167.1), the single nucleotide polymorphism (SNPs) of these genes and 2 splicing variants of the ST6GAL1 cDNA. RT-qPCR analysis showed that LALBA and ST6GAL1 were the genes with the highest and lowest expression in both breeds, respectively. The interaction effects of the breeds and sampling times were associated with higher levels of B4GALT1 and ST3GAL5 gene expression in Garganica than in Maltese goats at kidding. B4GALT1, LALBA, and ST3GAL5 gene expression changed from kidding to 60 and 120 days in Maltese goats, while in Garganica goats, a difference was observed only for the LALBA gene. Breed and lactation effects were also found for SOS contents. Positive correlations of B4GALT1, LALBA, ST3GAL5, and ST6GAL1 with 3'-SL/6'SL and DSL were found.

Conclusions: The genetic effect on the oligosaccharide content of milk was previously highlighted in bovines, and this study is the first to investigate this effect in two goat breeds (Garganica and Maltese) during lactation. The genetic variability of candidate genes involved in SOS biosynthesis highlights their potential role in affecting gene expression and ultimately biological function. The investigation of gene regulatory regions as well as the examination of other sialyltransferase genes will be needed to identify the genetic pattern leading to a higher SOS content in the autochtonous Garganica breed and to protect it using a focused breeding strategy.
\end{abstract}

Keywords: Oligosaccharides, RT-qPCR, B4GALT1, ST3GAL5, ST6GAL1, LALBA, Milk somatic goat cells, Colostrum cells

\footnotetext{
* Correspondence: alessandra.crisa@crea.gov.it

${ }^{1}$ CREA - Research Centre for Animal Production and Acquaculture, Via Salaria,

31, 00015 Monterotondo, RM, Italy

${ }^{2}$ S.S. 7 Via Appia, 85051 Bella Muro, PZ, Italy
}

(c) The Author(s). 2019 Open Access This article is distributed under the terms of the Creative Commons Attribution 4.0 International License (http://creativecommons.org/licenses/by/4.0/), which permits unrestricted use, distribution, and reproduction in any medium, provided you give appropriate credit to the original author(s) and the source, provide a link to the Creative Commons license, and indicate if changes were made. The Creative Commons Public Domain Dedication waiver (http://creativecommons.org/publicdomain/zero/1.0/) applies to the data made available in this article, unless otherwise stated. 


\section{Background}

Carbohydrates and, in particular, their oligosaccharidic fraction are part of the plethora of milk components that have functional health benefits for consumers. Oligosaccharides (OS) are synthesized in the mammary gland, contain between 3 and 10 monosaccharides, and can be divided into neutral and acidic fractions. The five principal monosaccharides component of milk OS are: Dglucose (Glc), D-galactose (Gal), N-acetylglucosamine (GlcNAc), L-fucose (Fuc), and sialic acid (Sia, specifically $\mathrm{N}$-acetylneuraminic acid [Neu5Ac] in humans and both Neu5Ac and N-glycolyl neuraminic acid [Neu5Gc] in most other species). Lactose (Galb1-4Glc) forms the reducing end of milk OS; 3 '-SL and 6' -SL can be synthesized by the addiction of Sia to Gal in $\alpha 2-3$ and/or $\alpha 2-6$ linkages, respectively. Lactose can also be fucosylated in $\alpha 1-2, \alpha 1-3$ linkages to form 2 'fucosyllactose (2-FL) and 3 'fucosyllactose $\left(3^{\prime}\right.$-FL), respectively. These trisaccharides are referred to as short-chain milk OS $[1,2]$. Moreover, if a sialic acid is added in an $\alpha-2-8$ linkage to $3{ }^{\prime}$ $\mathrm{SL}$, the disialyllactose (DSL) tetrasaccharides is formed.

It is generally accepted that most OS are resistant to the $\mathrm{pH}$ of the stomach in infants; they are also resistant to enzymatic hydrolysis in the small intestine and are thus largely undigested and unabsorbed. Therefore, most OS will pass through the intestinal tract and enter the colon intact [3].

Different healthful properties have been attributed to OS; they exhibit several protective and physiological roles, including showing prebiotic activity and inhibition of pathogen adhesion in the gastrointestinal tract of infants, immunoregulation, modulation of the microbiota in neonates, intestinal barrier protection, and participation in cognitive function development. The biological functions of $O S$ in human health and nutrition have been demonstrated by a vast number of functional in vitro and in vivo studies [4-7].

OS concentrations is high in the colostrum (up to $50 \mathrm{~g}$ / $\mathrm{L}$ or more) with an average of $10-15 \mathrm{~g} / \mathrm{L}$ in mature human milk [8]. Compared with humans, the concentration of OS in the milk of the most relevant domestic species is lower by a factor of 10 to 100 [9]. Moreover, higher OS concentrations have been reported in the colostrum than during late lactation in different animal species [10-12].

Goats produce milk containing free milk OS at much higher levels than cattle or sheep and with a variability, similar to those of human milk [13, 14]. Therefore goat milk also present potential as a supplement for infant formulae and for the development of functional foods or animal feedstuffs on an industrial scale $[15,6]$. The recovery and exploitation of whey (rich in OS) by membrane technology during cheesemaking may add value and encourage a decrease in environmental pollution [14-19].
In the last decade, scientists moved beyond the investigation of the components of milk itself and examined the genomics, transcriptomics and proteomics of milk; an example is provided by the Milk Genomics Consortium [20]. To understand the complex biology of milk OS metabolism, it is important to identify the genes that encode glycosylation-related enzymes and, in human, some investigation on glycosylation-related genes and their expression have been carried out [21, 22]. Harduinleper [23] reported a comprehensive analysis of sialyltransferase in vertebrate genomes; however, the mechanisms regulating differential gene expression in the mammary gland or milk somatic cells of dairy animals are still almost unknown. Sialyltransferases are a subset of glycosyltransferases that use cytidine-5'-monophospho-N-acetylneuraminic acid (CMP-Neu5Ac) as an activated sugar donor to catalyse the transfer of sialic acid residues to terminal non-reducing positions in the OS chains of glycoproteins and glycolipids. They catalyse the formation of different linkages $(\alpha 2-3, \alpha 2-6$, and $\alpha 2-$ 8 ) and differ in their acceptors. They have been grouped into four families according to the carbohydrate linkages that they synthesize: $\alpha$ 2-3-syaliltransferase (ST3Gal IVI), $\alpha$ 2-6-syaliltransferase (ST6GALI-II), GalNAc $\alpha 2-$ 6-syaliltransferase (ST6GalNAc I-VI), $\alpha$ 2-8- syaliltransferase (ST8Sia I-VI) [24-26].

Beyond physiological (age, kidding, body weight, stage, and number of lactations), environmental and management factors, milk characteristics are influenced by animal genetics (breed and genotype) [27, 28].

The study of OS biosynthesis genes and the identification of polymorphisms associated with naturally occurring OS types, in economically important dairy species and breeds, represents the first step to plan genetic improvement programs and to forecast technological/industrial applications.

In both cattle [12, 29-31] and goats [28, 32], differences in the OS profiles of milk have been found between breeds, and a higher concentration of sialylated oligosaccharides (SOS) fractions has been reported.

Dairy goats are of economic and social importance in southern Italy due to their ability to use vegetation in marginal areas. The Maltese goat represents the lactating goat "par excellence" of the Mediterranean, and the trinomial "rusticity- absence of horns- milk production" is still valid. The absence of horns plays a fundamental role in intensive and semi-intensive breeding. The Garganica breed is an autochthonous breed of economic importance on the Gargano Promontory. It represents a wager in the optics of sustainable and multifunctional breeding (environmental protection), particularly in internal and mountain areas, and the characterization of its milk and derivatives is a key element for the protection of the breed. 
We focused on the free OS fraction of goat milk and, in particular, the sialylated fraction; these prebiotic molecules have been shown to have many beneficial effects in the human body and, overall, in the gut [33, 34]. A first crucial step is to determine which glycosylationrelated genes are involved in the biosynthesis of OS in goat milk somatic cells.

The aims of this study are as follows: 1) identification of the complete cDNAs of three candidate genes potentially implicated in SOS biosynthesis. We decided to study beta-1,4-galactosyltransferase 1 (B4GALT1) and lactalbumin alpha ( $L A L B A)$ related to lactose synthesis (the precursor molecule for $3^{\prime}-\mathrm{SL}$ and $6^{\prime}$-SL biosynthesis), beta-galactoside alpha-2,3-sialyltransferase 5 (ST3GAL5) related to 3'-SL biosynthesis and betagalactoside alpha-2,6-sialyltransferase 1 (ST6GAL1) related to 6'-SL biosynthesis; 2) expression analysis of B4GALT1, LALBA, ST3GAL5, and ST6GAL1 by RTqPCR in the goat colostrum/milk somatic cells (GMSCs) of Garganica and Maltese breeds at four lactation stages (kidding, 1, 60, 120 days); and 3) investigation of $3{ }^{\prime}$-SL, 6 '-SL and DSL contents and correlation analysis of the different studied phenotypes (gene expression and/or SOS).

\section{Results}

\section{Sequencing analysis of the B4GALT1, ST3GAL5 and ST6GAL1 genes}

In this work, we identified the expressed complete coding cDNAs of three genes potentially involved in oligosaccharide metabolism. For DSL, we designed primers for the $\alpha$-N-acetyl-neuraminide $\alpha$-2,8-sialyltransferase 6 (ST8SIA6) gene [35], but we encountered problems with cDNA amplification, and we did not study this gene further (data not shown).

The B4GALT1 coding sequence obtained up from the assembly of two PCR amplicons; it is 1508 bp long, gives rise to an open reading of 1209 nucleotides, is composed of six exons and encodes a polypeptide of 402 amino acids. Two initial ATG codons are present, similar to the known mammalian B4GALT1 long isoform of the transcript. The sequence was deposited in GenBank under accession number HQ700335.1. The cDNA sequences from 8 Maltese milk samples revealed the presence of 2 SNPs in the 3'UTR (n.1294 G > A; n.1348 G > A). The deduced protein sequences showed identity with the four functional domains of the B4GalT-1 protein; comparison with the bovine sequence showed an overall similarity of $95.52 \%$, with 18 amino acid differences throughout the coding sequences.

The complete ST3GAL5 cDNA was compiled by merging the sequences of three amplicons; it is $1358 \mathrm{bp}$ long, gives rise to an open reading frame of 1263 nucleotides, is composed of seven exons and encodes a protein of
420 amino acids. Comparison of the predicted ST3GAL5 goat protein with the bovine protein showed $97 \%$ identity and 13 amino acid differences throughout the coding sequences. The sequence was deposited in GenBank under accession number KF055858.2. Sequencing of the cDNAs from 8 Maltese milk samples showed the presence of 2 SNPs: c. $213 \mathrm{G}>\mathrm{A}$ in exon 2 and c. $240 \mathrm{~T}>\mathrm{C}$ in exon 3. The first causes an amino acid change from Gly to Asp (aa67), and the second causes an amino acid change from Phe to Ser (aa76). The SIFT analysis predicted that Gly67Asp in exon 2 is tolerated (score 0.329), while Phe76Ser substitution in exon 3 is predicted to be deleterious for protein function (score 0.00).

The complete ST6GAL1 cDNA was compiled from the assembly of two PCR amplicons; it is 1672 bp long, spans a coding region of 1218 nucleotides, is composed of five coding exons and encodes a protein of 414 amino acids. Comparison of the predicted ST6GAL1 goat protein with the bovine protein showed $98 \%$ similarity and 10 amino acid differences, most of which were located in the first 90 amino acids. The sequence was deposited in GenBank under accession number HQ709167.1. In Fig. 1 , the results of PCR gel electrophoresis of the $1593 \mathrm{bp}$ amplicon from the cDNAs of 3 Maltese milk samples are shown. Sequences analysis of the weak bands indicated by arrows showed that the slower band corresponds to a cDNA with a spliced coding exon 2 and the faster band to a cDNA with a spliced coding exon 1 .

Sequencing of cDNA from 8 Maltese milk samples showed the presence of 4 SNPs: c. $372 \mathrm{~T}>\mathrm{A}$ and c.533 $\mathrm{G}>\mathrm{A}$ in exon 1, c.977 $\mathrm{C}>\mathrm{T}$ in exon 4 and c.1310 $\mathrm{C}>\mathrm{T}$ in exon 5 . The first three SNPs cause synonymous amino acid changes, while the c. $372 \mathrm{~T}>\mathrm{A}$ SNP causes a Ser versus Thr amino acid change (aa69). The SIFT analysis predicted this substitution in exon 1 to be tolerated for protein function (score 0,59 ).

\section{Gene expression analysis of B4GALT1, LALBA, ST3GAL5 and ST6GAL1 during lactation}

In this work, we aimed to study the expression of four genes (B4GALT1, LALBA, ST3GAL5, ST6GAL1) during lactation in two genetically distant goat breeds characterized by different productive traits. As an initial step, optimization of the primer concentration, annealing temperature and PCR efficiency was performed for all primer pairs used for both target and RGs. The results showed that a PCR efficiency of $92-105 \%$ of was achieved with the settled parameters (Additional file 1). The geNormPLUS analysis showed that $A T P 5 B$ and $S D H$ were the two most stable RGs (Additional file 2). For one MA and two GA animals, the 120-day sampling time point could not be analysed (dry-off). All procedures followed for the qPCR experiments complied with the Minimum Information for the Publication of 


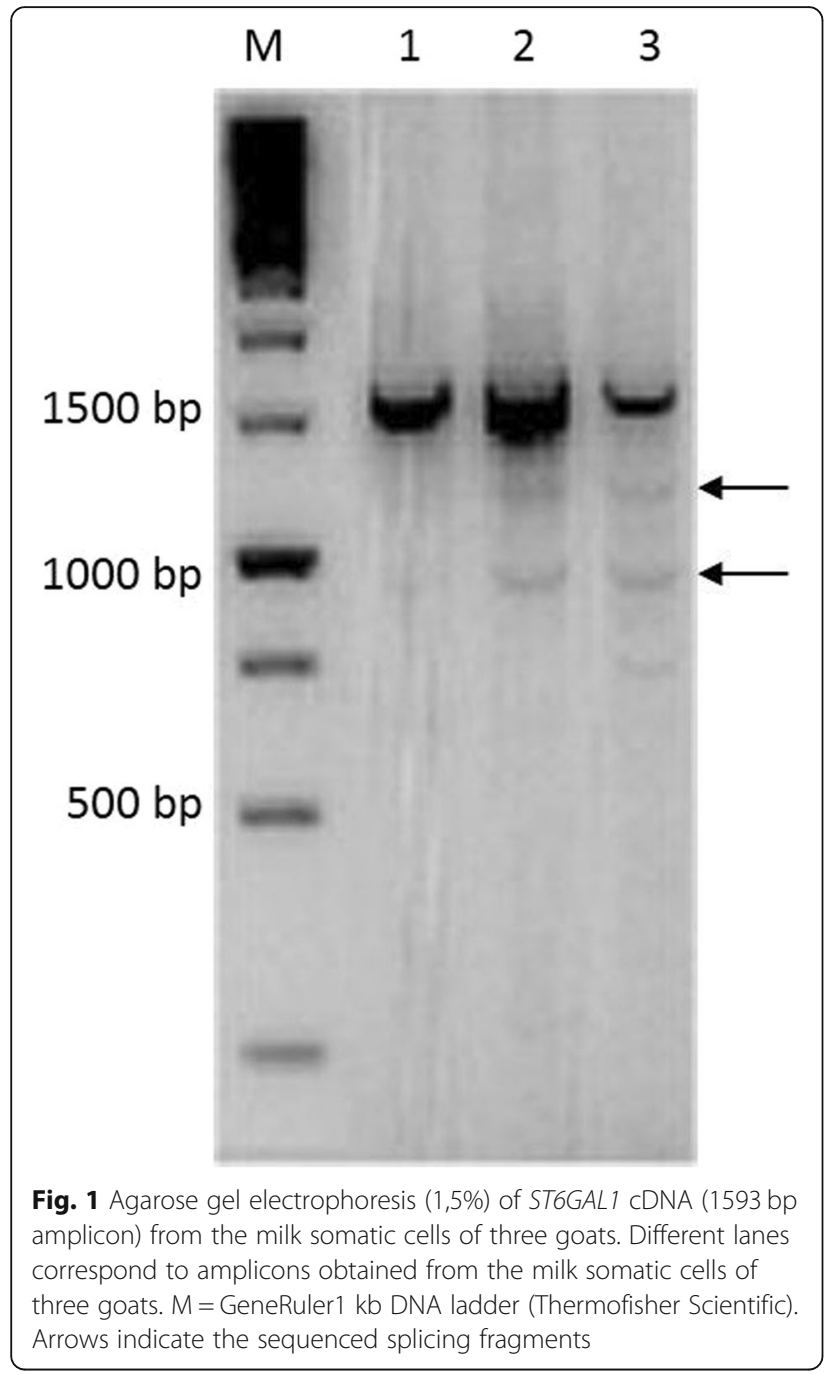

Quantitative Real-time PCR Experiments (MIQE) guidelines [36].

The effects of breed and lactation on gene expression are reported in Tables 1, while the effects of the interaction between the breeds and sampling times on gene expression are reported in Table 2 and Fig. 2 (please insert Table 2 after line 197). In Fig. 2, statistically significant differences between breeds are reported.

$L A L B A$ was the most highly expressed gene, followed by ST3GAL5, B4GALT1 and ST6 (1.206, 1.171, 0.695, and 0.6 mean values, respectively). A breed effect was found for ST3GAL5, whose expression was higher in GA. Lactation effects were shown for all genes except for ST6GAL1. In particular, B4GALT1 expression increased from 0 to 60 days, $L A L B A$ expression increased from 0 and 1 day to 60 and 120 days, and ST3GAL5 expression increased from 0 to 1,60 and 120 days (please insert here Table 2.

The breed/sampling time interaction effects of B4GALT1 and ST3GAL5 at day 0 were stronger in the GA breed ( $p=0.01$ and $p=0.014$, respectively). During lactation, B4GALT1 gene expression increased from 0 to 60 and 120 days only in the MA breed $(p=0.0026$ and 0.0016 , respectively). $L A L B A$ showed an increase from 0 to 60 days in the GA breed $(p=0.0025)$ and from 0 to 60 and 120 days in the MA breed ( $\mathrm{p}=0.0025$ and 0.00028 , respectively). ST3GALT5 expression increased from day 0 to 1,60 and 120 days in the MA breed $(0.0002 \leq$ $p \leq 0.01)$. No difference was observed for the ST6GAL1 gene between either lactation stages or breeds.

\section{Evaluation of oligosaccharide contents in colostrum and milk}

Overall, 3'-SL was the most abundant SOS, followed by DSL and 6'-SL (170.77 and $52 \mathrm{mg} / \mathrm{L}$ mean values, respectively). The evaluation of SOS contents in colostrum

Table 1 Effect of breed and sampling time on log10-transformed B4GALT1, LALBA, ST3GAL5, and ST6GAL1 CNRQ values

\begin{tabular}{|c|c|c|c|c|c|c|}
\hline & \multicolumn{2}{|l|}{ Breed } & \multicolumn{4}{|c|}{ Sampling time (days) } \\
\hline & $\mathrm{GA}$ & MA & 0 & 1 & 60 & 120 \\
\hline Gene & Lsmean \pm SE & Lsmean \pm SE & Lsmean \pm SE & Lsmean \pm SE & Lsmean \pm SE & Lsmean \pm SE \\
\hline B4GALT1 & $0.736 \pm 0.04$ & $0.668 \pm 0.04$ & $0.542 \pm 0.06^{\mathrm{b}}$ & $0.688 \pm 0.06^{\mathrm{ab}}$ & $0.802 \pm 0.06^{\mathrm{a}}$ & $0.776 \pm 0.07^{\mathrm{ab}}$ \\
\hline$\angle A L B A$ & $1.286 \pm 0.08$ & $1.193 \pm 0.08$ & $0.637 \pm 0.10^{B}$ & $1.024 \pm 0.10^{B}$ & $1.653 \pm 0.10^{A}$ & $1.644 \pm 0.13^{\mathrm{A}}$ \\
\hline ST3GAL5 & $1.262^{\mathrm{a}} \pm 0,06$ & $1.081^{b} \pm 0,06$ & $0.831 \pm 0,08^{B}$ & $1.281 \pm 0.08^{\mathrm{A}}$ & $1.381 \pm 0.08^{\mathrm{A}}$ & $1.191 \pm 0.10^{A}$ \\
\hline ST6GAL1 & $0,551 \pm 0.05$ & $0,654 \pm 0.05$ & $0,545 \pm 0,07$ & $0.579 \pm 0.07$ & $0.706 \pm 0.07$ & $0.580 \pm 0.08$ \\
\hline
\end{tabular}

Lsmean = estimated mean

$\mathrm{SE}=$ standard error

Uppercase superscripts within rows indicate significantly different LS means at $P<0.001$

Lowercase superscript within columns indicates significantly different LS means at $P<0.01$

$\mathrm{CNRQ}=$ calibrated normalized relative quantities

$B 4 G A L T 1=\beta-1,4-$ galactosyltransferase 1

$\angle A L B A=$ lactalbumin- $a$

ST3GAL5 $=\beta$-galactoside $\alpha-2,3$-sialyltransferase 5

ST6GAL1 $=\beta$-galactoside $\alpha-2,6$-sialyltransferase 1 
Table 2 Effect of interaction between breed and sampling time on log 10 transformed B4GALT1, LALBA, ST3GAL5, ST6GAL1 CNRQ values

\begin{tabular}{|c|c|c|c|c|c|c|c|c|c|c|c|c|c|c|c|}
\hline \multirow[b]{3}{*}{ Gene } & \multirow[b]{3}{*}{ Breed } & \multicolumn{8}{|c|}{ Sampling time (days) } & \multirow{3}{*}{$\begin{array}{l}\text { P0> } \\
1\end{array}$} & \multirow[b]{3}{*}{$\begin{array}{l}P 0> \\
60\end{array}$} & \multirow[b]{3}{*}{$\begin{array}{l}P 0> \\
120\end{array}$} & \multirow[b]{3}{*}{$\begin{array}{l}\mathrm{P} 1> \\
60\end{array}$} & \multirow[b]{3}{*}{$\begin{array}{l}\mathrm{P} 1> \\
120\end{array}$} & \multirow[b]{3}{*}{$\begin{array}{l}P 60> \\
120\end{array}$} \\
\hline & & $\overline{0}$ & & 1 & & 60 & & 120 & & & & & & & \\
\hline & & $\begin{array}{l}\text { Lsmean } \pm \\
\text { SE }\end{array}$ & $P$ & Lsmean \pm SE & $P$ & $\begin{array}{l}\text { Lsmean } \pm \\
\text { SE }\end{array}$ & $P$ & Lsmean \pm SE & $P$ & & & & & & \\
\hline$B 4 G A L T 1$ & GA & $0.78 \pm 0.09^{a}$ & 0.01 & $0.68 \pm 0.09$ & n.s. & $0.76 \pm 0.09$ & n.s. & $0.72 \pm 0.10$ & n.s. & n.s. & n.s & n.s & n.s. & n.s. & n.s. \\
\hline$B 4 G A L T 1$ & MA & $\begin{array}{l}0.30 \pm \\
0.09^{\mathrm{Bb}}\end{array}$ & & $0.70 \pm 0.09^{\mathrm{AB}}$ & & $\begin{array}{l}0.84 \pm 0.09 \\
A\end{array}$ & & $0.83 \pm 0.10^{A}$ & & n.s. & 0.0026 & 0.00116 & n.s. & n.s. & n.s. \\
\hline$\angle A L B A$ & GA & $0.80 \pm 0.15^{\mathrm{B}}$ & n.s. & $\frac{1.07}{A B} \pm 0.15$ & n.s. & $1_{A}^{1.75} \pm 0.15$ & n.s. & ${ }_{A B}^{1.53} \pm 0.18$ & n.s. & n.s. & 0.0025 & n.s & n.s. & n.s. & n.s. \\
\hline$\angle A L B A$ & MA & $0.47 \pm 0.15^{\mathrm{B}}$ & & ${ }_{A B}^{0.98} \pm 0.15$ & & $1_{A} .56 \pm 0.15$ & & ${ }_{\mathrm{AC}}^{1.75} \pm 0.18$ & & n.s. & 0.0005 & 0.00028 & n.s. & n.s. & n.s. \\
\hline ST3GAL5 & GA & $1.14 \pm 0.11^{\mathrm{a}}$ & 0.014 & $1.42 \pm 0.11$ & n.s. & $1.33 \pm 0.11$ & n.s. & $1.15 \pm 0.14$ & n.s. & n.s. & n.s. & n.s. & n.s. & n.s. & n.s. \\
\hline ST3GAL5 & MA & $\begin{array}{l}0.52 \pm \\
0.11^{\mathrm{Bb}}\end{array}$ & & $1.14 \pm 0.11^{\mathrm{A}}$ & & $1.42 \pm 0.11^{\mathrm{A}}$ & & $1.23 \pm 0.14^{\mathrm{A}}$ & & 0.013 & 0.0002 & 0.01 & n.s. & n.s. & n.s. \\
\hline ST6GAL 1 & GA & $0.58 \pm 0.10$ & n.s. & $0.50 \pm 0.10$ & n.s. & $0.64 \pm 0.10$ & n.s & $0.46 \pm 0.12$ & n.s & n.s. & n.s. & n.s & n.s. & n.s. & n.s. \\
\hline ST6GALI & MA & $0.50 \pm 0.10$ & & $0.65 \pm 0.10$ & & $0.77 \pm 0.10$ & & $0.69 \pm 0.12$ & & n.s. & n.s. & n.s & n.s. & n.s. & n.s. \\
\hline
\end{tabular}

Lsmean = estimated mean

$\mathrm{SE}=$ standard error

n.s. $=$ not significant

Uppercase superscripts within rows indicates significantly different LS means between sampling times

Lowercase superscript within columns indicates significantly different LS means between breeds

$P$-values of the differences between sampling times are reported in the last six columns

$\mathrm{CNRQ}=$ Calibrated normalized relative quantities

$B 4 G A L T 1=\beta-1,4-$ galactosyltransferase 1

$\angle A L B A=$ lactalbumin-a

ST3GAL5 $=\beta$-galactoside $a-2,3$-sialyltransferase 5

ST6GAL1 = $\beta$-galactoside $\alpha-2,6$-sialyltransferase 1

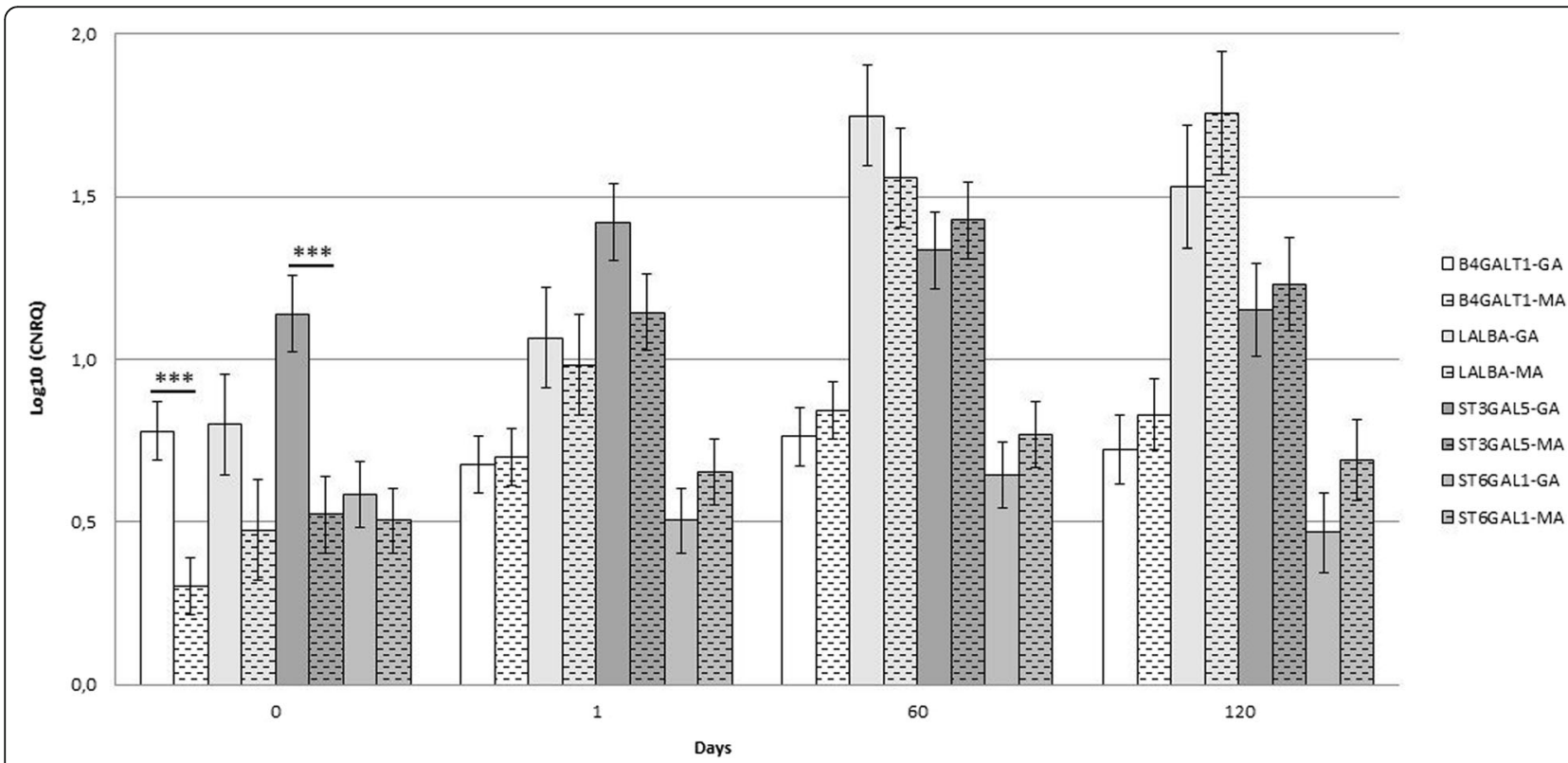

Fig. 2 BAGALT1, LALBA, ST3GAL5, and ST6GAL1, gene expression in the Garganica (GA) and Maltese (MA) breeds during lactation. Lsmean values of log10-transformed cumulative normalized relative quantities (CNRQ) for the B4GALT1, LALBA, ST3GAL5 and ST6GAL1 genes in Garganica (GA) and Maltese (MA) somatic cell samples in colostrum (0,1 days) and milk (60,120 days). Uniform and dashed coloured boxes represent the Garganica and Maltese breeds, respectively. Statistically significant differences in the expressed genes between breeds are represented. ${ }^{* * *} P<0.001$ 
and milk showed a significant effect of the breed and sampling time (Table 3).

A breed effect was shown for DSL at a higher concentration in MA. A sampling time effect was observed for all the SOS. In particular, the 3 '-SL content decreased from 0 and 1 days to 60 and 120 days; the $6^{\prime}$-SL content increased from 0 to 1 days and then decreased from 60 and 120 days; and the DSL content decreased from 0 and 1 days to 60 and 120 days.

Considering the interaction effect (Table 4), differences between breeds were observed at 1 day, when 3 '-SL values were higher in GA $(p=0.032)$, and DSL was higher in MA $(p=0.0001)$. (please insert here Table 4). During lactation, decreases in the contents of all SOS were observed from 1 to 60 days in both breeds, whereas there was an increase in 6 ' $-\mathrm{SL}$ from 0 to 1 days. The 3'-SL content increased from 0 to 1 day only in GA, while DSL decreased.

\section{Correlation analysis between the analysed phenotypes} Pearson's correlation coefficients between the studied phenotypes throughout the experiment (gene expression levels and SOS contents) are shown in Table 5.

Regarding gene expression, we observed moderate statistically significant correlations between B4GALT1 and LALBA ( $\mathrm{r}=0.46139 ; p=0.0014)$ and between B4GALT1 and ST6GAL1 $(\mathrm{r}=0.51407 ; p=0.0003)$. Regarding SOS, a strong correlation between $6^{\prime}-\mathrm{SL}$ and $3^{\prime}-\mathrm{SL}(\mathrm{r}=$ $0.72745 ; p<0.0001)$ and moderate correlations between $6^{\prime}-\mathrm{SL}$ and DSL $(\mathrm{r}=0.42474 ; p=0.0041)$ and between $3^{\prime}$ SL and DSL $(r=0.55351 ; p<0.0001)$ were found. Finally, the correlations between gene expression and oligosaccharides were moderate and were found for $L A L B A$ with $6^{\prime}-\mathrm{SL} \quad(\mathrm{r}=-0.43280 ; p=0.0033), \quad 3{ }^{\prime}-\mathrm{SL} \quad(\mathrm{r}=-054178$; $p=0.0001)$, and DSL $(\mathrm{r}=-0.64733 ; \mathrm{p}<0.0001)$.

\section{Discussion}

To our knowledge, this study is the first to investigate the gene expression of candidate genes for OS biosynthesis in different goat breeds during four lactation stages. In fact, only one RNA-seq experiment in the Jersey and Friesian bovine breeds [37] and one in the Maltese goat breed [38] have been reported to date. The identification of the candidate gene cDNAs represents a first step toward gene expression analysis.

The mutations found in the ST3GAL5 coding cDNA lead to amino acid changes in the protein transmembrane domain (TM).

Compared with other Golgi-resident glycosyltransferases (GT), the deduced proteins of both ST3GAL5 and ST6GAL1 shared a typical type II membrane protein topology (consisting of a short $\mathrm{N}$-terminal cytoplasmic tail, a transmembrane (TM) domain followed by a stem region and a large $\mathrm{C}$-terminal catalytic domain facing the luminal side) and sialyl motifs in their catalytic domain [39, 40].

The Phe76Ser change $($ c. $240 \mathrm{~T}>\mathrm{C})$ identified in the ST3GAL5 cDNA is located in the middle of the sequence, and SIFT prediction showed the mutation to be deleterious for protein function. The $\mathrm{N}$-terminal region of glycosyltransferases, and particularly the transmembrane domain, is crucial for the correct Golgi localization of the enzymes [41]. a change from an apolar to a polar in amino acid residue the hydrophobic TM could interfere with the correct localization of an enzyme and, consequently, its function. In humans, a missense change in the TM region of an ST3GAL3 family protein was shown to co-segregate with intellectual disability, and cellular and biochemical systems showed that this mutation caused ER retention and drastically impaired protein functionality [42]. It would be interesting to investigate the c. $240 \mathrm{~T}>\mathrm{C}$ mutation more deeply in at least the two goat breeds examined herein and in a larger number of animals to uncover its potential influence on gene expression.

The Ser69Thr amino acid change (caused by the c.372 T > A SNP) found in the ST6GAL1 cDNA is located in the stem region outside of the catalytic region of the

Table 3 Effects of breed and sampling time on SOS content

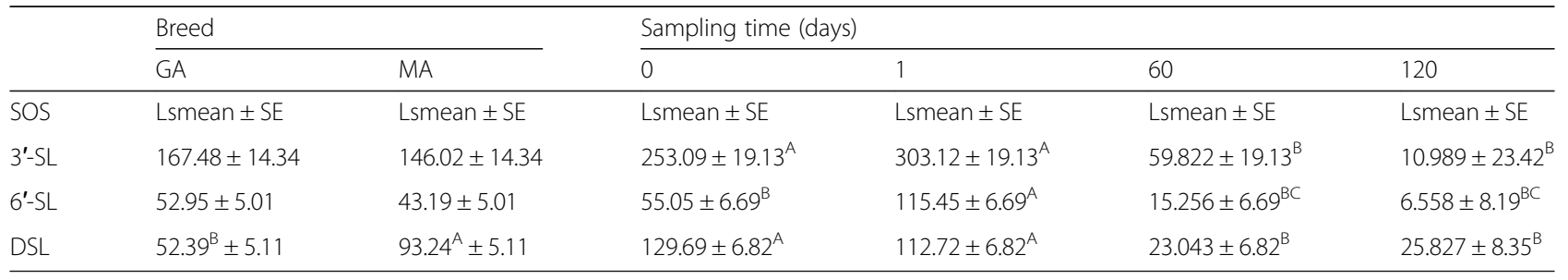

The SOS concentration is reported as $\mathrm{mg} / \mathrm{L}$

Lsmean $=$ estimated mean

$\mathrm{SE}=$ standard error

Uppercase superscripts within rows indicate significantly different LS means at $P<0.001$

SOS = sialyloligosaccharides

$6^{\prime}$-SL $=6^{\prime}$ sialyllactose

3'SL = 3'sialyllactose

$\mathrm{DSL}=$ disialyllactose 
Table 4 Effect of interaction between breed x sampling time on SOS content

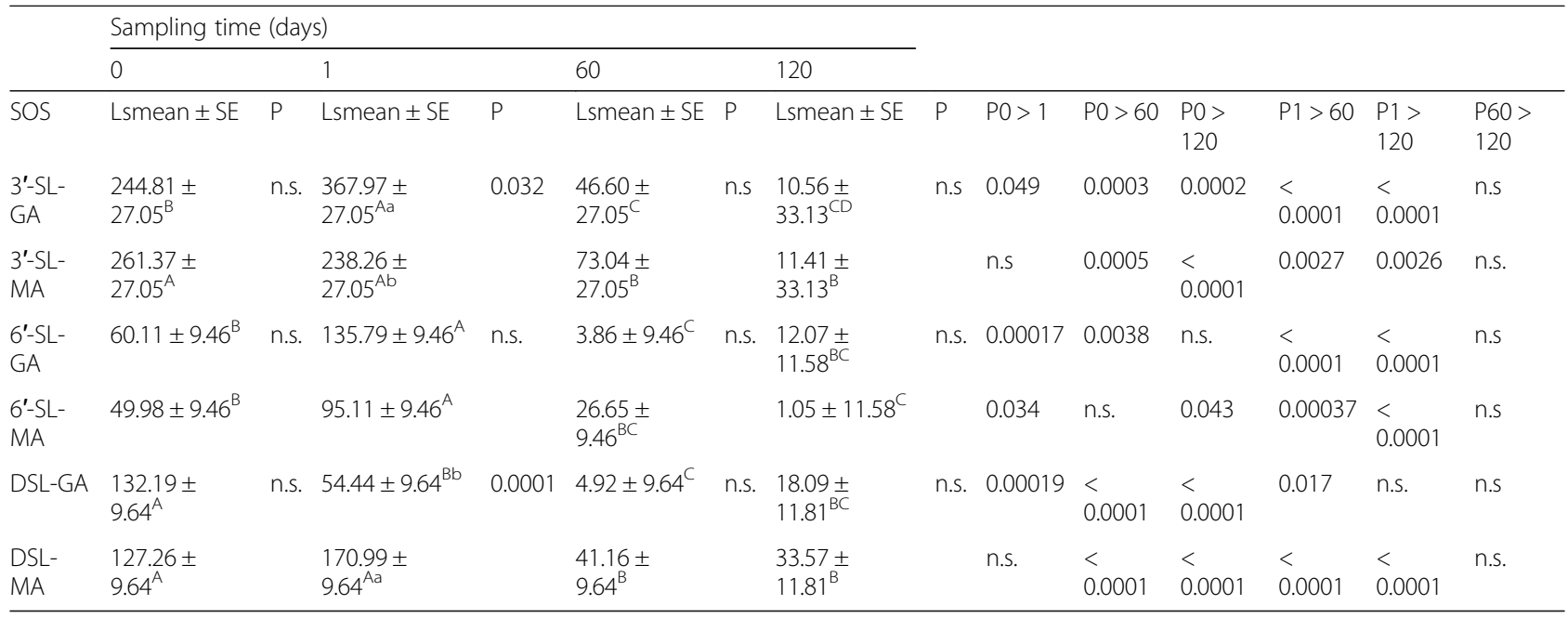

SOS = sialyloligosaccharides

The SOS concentration is reported as $\mathrm{mg} / \mathrm{L}$

Uppercase superscripts within rows indicate significantly different LS means between sampling times

Lowercase superscripts within columns indicate significantly different LS means between breeds

P-values of the differences between sampling times are reported in the last six columns

Lsmean = estimated mean

$\mathrm{SE}=$ standard error

$6^{\prime}-\mathrm{SL}=6^{\prime}$ 'sialyllactose

3'SL = 3'sialyllactose

$\mathrm{DSL}=$ disialyllactose

protein, and SIFT analysis did not show deleterious effects on protein function. Considering the preliminary identification of ST6GALT1 splicing variants in GMSCs, the obtained bands were less distinct compared with the principal band. Moreover, the higher band gives rise to a deduced protein product lacking the second coding exon containing the entire L sialyl motif of the catalytic domain, while the lower band gives rise to a protein lacking the TM domain. Thus, these bands would not produce a complete protein, although the full transcript could compensate for this, or they might represent expressed pseudogene forms. as reported for bovines [43].

The whey $\alpha$-lactalbumin protein coding gene (LALBA) showed the highest expression in our experiment, which agrees with previous findings in goats [44], cows [45], sheep [46] and humans [47]. The increase in $L A L B A$ expression that we observed starting from the colostrum stage was consistent with increases in both the milk protein output and lactose synthesis. LALBA is a major protein component of whey, and a high level of $L A L B A$ expression in mammary epithelial cells is required

Table 5 Pearson's correlation coefficients between the levels of gene expression and sialyl oligosaccharides throughout the experiment

\begin{tabular}{|c|c|c|c|c|c|c|}
\hline & $\angle A L B A$ & ST3GAL5 & ST6GAL1 & $6^{\prime}-S L$ & 3'-SL & DSL \\
\hline B4GALT1 & $0.46139 * *$ & $0.35082^{*}$ & $0.51407^{* * *}$ & -0.07286 & $-0.37569^{*}$ & -0.26596 \\
\hline LALBA & & $0.32301^{*}$ & 0.11308 & $-0.43280^{* *}$ & $-0.54178^{* * *}$ & $-0.64733^{* * *}$ \\
\hline ST3GAL5 & & & 0.21658 & 0.06751 & -0.13598 & $-0.34050^{*}$ \\
\hline ST6GAL1 & & & & -0.22778 & -0.24191 & 0.04724 \\
\hline $6^{\prime}-S L$ & & & & & $0.72745^{* * *}$ & $0.42474^{* *}$ \\
\hline $3^{\prime}-S L$ & & & & & & $0.55351^{* * *}$ \\
\hline DSL & & & & & & \\
\hline
\end{tabular}

Pearson coefficient significance: ${ }^{*} P<0.05 ;{ }^{*} P<0.01 ;{ }^{* * *} P<0.001$

$B 4 G A L T 1=\beta-1,4-$ galactosyltransferase 1

$\angle A L B A=$ lactalbumin- $\alpha$

ST3GAL5 $=\beta$-galactoside $\alpha-2,3$-sialyltransferase 5

ST6GAL1 $=\beta$-galactoside $\alpha-2,6$-sialyltransferase 1

$6^{\prime}-\mathrm{SL}=6^{\prime}$ 'sialyllactose

3'SL = 3'sialyllactose

$\mathrm{DSL}=$ disialyllactose 
during lactation. At 120 days, $L A L B A$ values were shown to be high in MA, while in GA, they tended to decrease; we hypothesize that this trend could be related to the longer lactation period of the MA than the GA breed. In the mammary gland, B4GalT-1 interacts with the $\alpha$ lactalbumin protein to form the lactose synthase complex which is involved in the final step of lactose synthesis by transferring the galactose moiety of free UDP-Gal to Glc rather than to GlcNAc [7]. Although this process has been demonstrated to occur in intact Golgi, the precise mechanisms whereby lactose is modified by the addition of other sugars by specific glycosyltransferases during lactation are still unknown. It is assumed that the same enzymes involved in producing the termini of other glycan classes might be responsible. The B4GALT1-encoded protein is one of the best-studied galactosyltransferase enzymes; it is a trans-Golgi resident type II membrane-bound glycoprotein that catalyses the transfer of galactose to $\mathrm{N}$-acetylglucosamine residues and participates in the biosynthesis of the oligosaccharide structures of glycans. Since B4GalT-1 has been identified on the plasma membrane, it may also be involved in cell-cell or cell-substrate recognition [48]. B4GALT1 gene expression was maintained at similar levels during lactation in the GA breed, while increasing expression values were shown in the MA breed; the latter is in agreement with the results reported in an RNA-seq experiment in goat [38].

The expression patterns of both $L A L B A$ and B4GALT1 suggest that the encoded proteins are present during lactation and are assembled to carry out the production of lactose, which might in turn be used as a precursor for SOS biosynthesis. A moderate positive correlation coefficient between the B4GALT1 and LALBA genes was found in the experiment, supporting our hypothesis.

Considering the ST6GAL1 gene, its expression in bovines is primarily regulated at the transcription level by several cell and development-specific promoters, producing transcripts with divergent $5^{\prime}$ untranslated regions (UTR) [43]. In the mouse mammary gland [49], a novel mRNA isoform of the ST6GALI gene containing a novel 5 'UTR exon (L) that is associated with a drastic increase in gene expression during lactation has been identified. Dalziel et al. [50] found a similar transcript in the rat mammary gland. In contrast, no exon (L)-containing transcript was detected in the lactating bovine or human mammary gland. The authors also observed a trend of increasing ST6GAL1 gene expression in the bovine mammary gland, culminating in involution. This contrasts with findings in species such as mice, in which the greatest change in ST6GAL1 gene expression occurs between pregnancy and lactation, suggesting different roles in rodents vs. other mammals. The transcripts identified in this study showed differences in their coding regions, and we could not clarify the nature of the different $5^{\prime}$ regions of the transcripts because neither 5'RACE or a promoter analysis was performed.

The mammary gland is susceptible to modification and remodelling associated with cell turnover and apoptosis during lactation [51, 52]. On our experimental farm, the goats are extensively reared, and kids are left with parents for a long period until the peak of lactation, when they are separated. At the beginning of weaning in the mammary gland, some modifications lead to involution; Li et al. [53] found that $5 \%$ of cells in the involuting tissue in goats were apoptotic, whereas less than $1 \%$ of cells in lactating tissue were undergoing death. During this phase, greater susceptibility to infection arises, with the consequent stimulation of the immune system, which plays an important role in the defence of the mammary gland. The review of Mills et al. [54] explains the possible roles of OS that harbour epitopes similar to selectin-binding ligands and may play a role in antiinflammatory processes.

We hypothesize that at 60 days, both the ST6GAL1 and ST3GAL5 genes might be expressed at higher levels due to their potential involvement in the synthesis of glycoconjugate sialylated structures, which are fundamental for the immune response.

Sialyltransferases are divided into four families, ST6Gal, ST3Gal, ST6GalNAc and ST8Sia, according to the glycosidic linkage formed and the monosaccharide acceptor used. Currently, 20 sialyltransferase subfamilies are known in higher vertebrates [23]. The ST3gal gene family comprises six ST3Gal sub-families, and the ST6Gal gene family comprises two sub-families. ST3Gal III, IV, V, and VI use the oligosaccharide isomers Gal $\beta 1-3 / 4$ Glc(NAc)-R.

RNA-seq studies in both goats [38] and bovines [37] showed the expression of all 6 sub-family ST3Gal genes, including ST3GAL5 and ST6GAL1. In goats, the most highly expressed genes were ST3GAL1, ST3GAL4 and ST3GAL6. Another study [55] found that the most highly expressed genes in mouse mammary glands were ST3GAL1, ST3GAL4 and ST6GAL1. By using knock-out mice for these genes and analysing $3^{\prime}$-SL and 6'SL levels in milk, it was shown that the ST3GAL4 and ST6GAL1 genes account for the bulk of 3 'SL and 6'-SL production, respectively.

When we looked at the possible correlations of the phenotypes analysed in the experiment, we found positive correlations among genes and among SOS. A positive correlation of ST3GAL5 and ST6GAL1 expression with $3^{\prime}$-SL and $6^{\prime}-\mathrm{SL}$ colostrum/milk contents was not found. In fact, the concentration of SOS was initially high in colostrum ( 0 and 1 day) and then decreased, in accordance with the literature $[11,32,56,57]$, while for gene expression, the opposite pattern was observed. 
The lack of association between some of the chosen candidate genes and SOS content might have occurred because other sialyltransferase genes such as ST3GAL4 or ST3GAL6 [58] might be involved in the biosynthesis of the free OS fraction.

Overall, the higher expression of ST3GALT5 to ST6GALT1 found in this study corresponds to the higher concentration of $3^{\prime}$-SL compared to $6^{\prime}-\mathrm{SL}$, which is supported by Crisà et al. [38] and Wickramasinghe et al. [37], who reported the same differences in gene expression in RNA-seq experiments in goats and cows.

The differences in SOS contents between the GA and MA goat breeds have been investigated by Claps et al. [32], although they sampled milk at different time points than were examined in the present study, and we could perform comparisons only for the results for 0 and 1 days. In their experiment, DSL showed the third highest mean value among the SOS after $3^{\prime}-\mathrm{SL}$ and $6^{\prime} \mathrm{SL}$, and GA colostrum and milk contained higher levels of 3 '-SL, $6^{\prime}$-SL and DSL than those of MA. In our experiment, DSL was the second most concentrated SOS after 3'SL, and the proportions of SOS between GA and MA differed on the different days. Only on day 1 did 3'-SL present a significantly higher value in GA, while DSL presented a higher value in MA. Given that DSL is formed from 3'-SL, we speculate that in MA, a fraction of $3^{\prime}$-SL might be used to synthesize DSL. This suggestion was corroborated by the results of correlation analyses in which higher and more statistically positive coefficients were found between 3 '-SL and DSL than between $6{ }^{\prime}$-SL and DSL.

Furthermore, we do not have data on the expression of ST8SIA genes that could support this suggestion. In mice, it was shown that the ST8SiaVI product exhibited higher activity towards 3 '-SL than towards 6' -SL [26].

A limitation of our study is that we considered only certain putative genes involved in the last step of SOS biosynthesis while not taking into account precursor availability for the sialic acid and lactose synthesis pathways. The goats were fed the same diet, so the diet would not be an issue explaining the observed differences, which could instead reflect an effect of parity (differences between experimental animals), season (from February to June), the duration of lactation (which is shorter in the GA breed) or production output (which is lower in the GA breed) effects. Moreover, we are aware that other intermediate biological processes exist between gene expression and the production of functional proteins.

\section{Conclusions}

This study represents the first attempt in investigating the mRNA expression profiles of candidate genes implicated in SOS biosynthesis in different goat breeds during lactation. Genetic effects on the OS content of milk have been observed in bovines, and we report candidate gene expression variability in two breeds of goats, one of which is autochthonous and economically important to the Gargano promontory. Moreover, the higher expression of ST3GALT5 with respect to ST6GALT1 corresponds to what has been reported in the literature regarding the higher concentration of 3 '-SL compared to $6^{\prime}$-SL in goat colostrum and milk. However, no clear correlation between genes and SOS contents in colostrum and milk was shown by the analysis. Although the investigation of additional sialyltransferase genes that support and explain SOS production is needed, our findings highlight the presence of SNPs in the studied genes, one of which might impair the protein cellular localization and function of ST3GAL5. The identification of different ST6GAL1 transcripts suggests the existence of a complex regulatory process in the promoter region, as observed in other mammalian species. The investigation of SNPs in the wider Maltese and Garganica population as well the gene regulatory regions, which may account for different transcripts or expression levels, will be needed to identify associations with OS milk content. Garganica is an important autochthonous goat breed, especially for interior and mountainous areas, and the identification of genetic patterns leading to higher SOS contents might be useful for breeding purposes and a key element for breed protection.

\section{Methods}

\section{Animals and sample collection}

This study was conducted on the experimental farm of CREA (Consiglio per la Ricerca in Agricoltura e l'Analisi dell'Economia Agraria, Research Centre for Animal Production and Acquaculture, Bella (PZ)), a research institute authorized by the Italian Ministry of Health to use farm animals for experimental purposes (DM 26/96-4). Animal management and care followed the recommendations of European Union directive 86/609/EEC.

A dairy breed, Maltese (MA) goats, and a less productive breed, Garganica goats (GA), were considered in this trial, including a total of 18 does (9 GA and $9 \mathrm{MA}$ ). The animals were fed indoors, receiving mixed meadow hay ad libitum plus concentrate supplementation at $14 \%$ of crude protein (CP), which was $600 \mathrm{~g} / \mathrm{d}$ for MA and 400 $\mathrm{g} / \mathrm{d}$ for GA in relation to their level of milk production. Within each breed, the animals were grouped homogenously according to their live weight $(46.1 \mathrm{~kg}$ and $48.6 \mathrm{~kg}$ on average for MA and GA, respectively) and milk production (1200 and $800 \mathrm{~g} /$ day of milk, respectively, in mid lactation).

At four lactation stages (colostrum (after kidding and day 1), 60 and 120 days), individual colostrum/milk samples were collected in a $50 \mathrm{ml}$ tube and transported to 
the laboratory at $4{ }^{\circ} \mathrm{C}$ for RNA extraction. For OS determination (3'-SL, 6'-SL, DSL), the samples were distributed in $10 \mathrm{ml}$ tubes and immediately frozen at $-20^{\circ} \mathrm{C}$ until analysis. At the fourth lactation stage, some samples were not collected because the ewes had run dry.

\section{RNA and DNA extraction}

RNA was obtained from goat milk somatic cells (GMSCs) in accord with both [59], who showed that GMSCs can be used to accurately reveal the cellular dynamics of mammary gland gene expression, and other authors $[60,61]$ who demonstrated extensive similarity between the mammary gland and MSC/ mammary epithelial cell transcriptomes. RNA was extracted from somatic cells obtained from $50 \mathrm{ml}$ of goat colostrum or milk in a total of 72 samples. Individual samples were immediately centrifuged at $2000 \mathrm{~g}$ for $10 \mathrm{~min}$ at $4{ }^{\circ} \mathrm{C}$ in the presence of $50 \mu \mathrm{l}$ EDTA $0.5 \mathrm{M} \mathrm{pH}$ 8. The fat layer on the top of the supernatant was removed with a sterile pipette tip, the skim milk was discarded, and the somatic cell pellet was resuspended in $1 \mathrm{ml}$ of $1 \mathrm{X}$ PBS with $300 \mu \mathrm{l}$ of $0.5 \mathrm{M} \mathrm{pH} 8$ EDTA and centrifuged again. The resulting cells were lysed with $1 \mathrm{ml}$ TriReagent (SigmaAldrich, Milan, Italy). Total RNA extraction was performed following the manufacturer's instructions. RNA was digested to remove contaminated DNAs with an RNase-Free DNase Set (Qiagen) and successfully cleaned with an RNeasy MinElute kit (Qiagen, Milan, Italy). RNA quality and quantity were checked via a spectrophotometry (NanoPhotometer ${ }^{\mathrm{rn}}$ Pearl, Implen GmbH, München, Germany) and microfluidic (2100 Bioanalyzer, Agilent Technologies, Milan, Italy) inspection to assess RNA integrity. The RNA samples were stored at $-80^{\circ} \mathrm{C}$. Only RNA with an RNA Integrity Number (RIN) $>7$ was used in the gene expression analyses (6 animals of each breed, total of 45 samples). DNA was extracted from the interphase obtained from milk cell pellets following the TriReagent (Sigma-Aldrich, Milan, Italy) manufacturer's instructions.

\section{Reverse transcription into CDNA and sequencing}

RNA was reverse transcribed to produce both long cDNAs and cDNAs for qPCR. In the first case, the Maxima H Minus First Strand cDNA Synthesis kit (Thermo Scientific, Thermo Fisher Scientific, Waltham, USA) was employed starting from $1 \mu \mathrm{g}$ of RNA in a total volume of $20 \mu \mathrm{l}$ containing $100 \mathrm{pmol}$ oligo (dT) (18-mer), $0.5 \mathrm{mM}$ dNTPs, 5X RT buffer, and Maxima H Minus Enzyme mix according to the manufacturer's instructions. The resulting cDNA was diluted 1:2 and PCR amplified by using the primer pairs listed in Table 1. PCR amplification was performed using Dream Taq DNA polymerase (Thermo Scientific, Thermo Fisher Scientific, Waltham, USA) with $1 \mu \mathrm{l}$ of the first-strand cDNA reaction and a touchdown protocol. The PCR products were gel purified using Nucleospin columns (Macherey-Nagel, GmbH \& Co KG, Duren, Germany) and bi-directionally sequenced by using the BidDye Terminator v. 1.1 Cycle Sequencing kit and an ABI 3700 sequencer (Applied Biosystems, Life Technologies, Milan, Italy).

For the cDNAs to be used in gene expression experiments, the Maxima First Strand cDNA synthesis kit for RT-qPCR (Thermo Scientific, Thermo Fisher Scientific, Waltham, USA) was used. Briefly, RT reactions were prepared by adding $500 \mathrm{ng} \mathrm{RNA}, 4 \mu \mathrm{l}$ of a $5 \mathrm{X}$ reaction mix (containing random hexamers and oligo $(\mathrm{dT})_{18}$, and $2 \mu \mathrm{l}$ of enzyme mix in a final volume of $20 \mu \mathrm{l}$. The reaction was incubated at $25^{\circ} \mathrm{C}$ for $10 \mathrm{~min}$, then at $50^{\circ} \mathrm{C}$ for $15 \mathrm{~min}$, and finally at $85^{\circ} \mathrm{C}$ for $5 \mathrm{~min}$. An RT-negative reaction was set up to check for genomic DNA contamination. The cDNA was first diluted 1:4 and then used directly for qPCR or stored at $-20^{\circ} \mathrm{C}$.

\section{Primer design and sequence analysis}

At the beginning of our study, no annotations for the studied genes in goats were present in GenBank except for LALBA (NM_001285635). Primers were picked by using Primer 3 software [62,63] on the basis of known bovine sequences. After initial trials with different primer pairs, the complete coding sequences of ST6GAL1, ST3GAL5, and B4GALT1 were obtained by merging the sequences from two or three amplicons (Table 6). Sequence analysis and alignments (nucleotidic and proteic deduced ones) were performed using DNAMAN (Version 4.15, Lynnon BioSoft, Inc., San Ramon, USA), Bio Edit software [64] and the BLAST tool $[65,66]$.

SIFT software analysis was performed to predict whether an amino acid substitution affects protein function based on sequence homology and the physical properties of amino acids [67].

Primer Express software (Applied Biosystem, Thermo Fisher Scientific, Waltham, USA) was used to design primers for $\mathrm{qPCR}$ on the basis of bovine sequences. Five reference genes (RGs) selected in another study [68] were tested here: ATP synthase $\beta$ polypeptide, a nuclear gene encoding a mitochondrial protein (ATP5B), eukaryotic translation initiation factor eIF-2B subunit $\beta$ (EIF2B2), succinate dehydrogenase complex subunit A flavoprotein $(S D H A)$, DNA-directed RNA polymerase fragment RNA polymerase II (POLR2A), and a TATA box-binding protein $(T B P)$. We designed and tested new primers for the following RGs: a ubiquitously expressed transcript (UXT) and ribosomal protein S9 (RPS9). The primers were intron spanning when possible and were synthesized by Eurofins MWG Operon (Ebersberg, Germany). Table 7 provides information related to the primers used to amplify the targets and RGs. Preliminary amplifications were performed on both cDNA and DNA 
Table 6 Primer sequences, reference sequences, position in the reference, T.a. and amplicon size of target genes

\begin{tabular}{|c|c|c|c|c|c|}
\hline Gene symbol & Primer sequences & Reference sequence & Position & T.a. & Amplicon base pair \\
\hline B4GALT1 & $\begin{array}{l}\text { FW-5'TAAAGCGGCGGCGGGAAGAT3' } \\
\text { RW-'5AATGAGAGGGACCAGCCCA3' }\end{array}$ & NM_177512.2 & $\begin{array}{l}166-185 \\
1460-1478\end{array}$ & 57 & 1313 \\
\hline B4GALT1 & $\begin{array}{l}\text { FW-5'GTTCTCAGCATCAATGGATTCCC3' } \\
\text { RW-5'GCTITGATTCTTTGGGTGA3' }\end{array}$ & NM_177512.2 & $\begin{array}{l}1083-1106 \\
1652-1672\end{array}$ & 58 & 590 \\
\hline ST3GAL5 & $\begin{array}{l}\text { FW-5'CCCGCTCCCTAATATGCGAA3' } \\
\text { RW-5'TGCGATCAGGATCCATGTAA3' }\end{array}$ & NM_205807 & $\begin{array}{l}30-49 \\
342-361\end{array}$ & 58 & 332 \\
\hline ST3GAL5 & $\begin{array}{l}\text { FW-5'AATGCCAAGTGACCACAGC3' } \\
\text { RW-5'CGACATCAAACTGGTTCAGG3' }\end{array}$ & NM_205807 & $\begin{array}{l}129-147 \\
684-704\end{array}$ & 58 & 460 \\
\hline ST3GAL5 & $\begin{array}{l}\text { FW-5'CCTGAACCAGTTGGATGTC3' } \\
\text { RW-5'CAGCATTGGAAGCACAGAGT3' }\end{array}$ & NM_205807 & $\begin{array}{l}684-704 \\
1369-1389\end{array}$ & 58 & 705 \\
\hline ST6GAL1 & $\begin{array}{l}\text { FW-5'TCCTGAGAAGAATGAGCCTTG3' } \\
\text { RW-5'AGTGAGACAGGAGGCTCTGG3' }\end{array}$ & NM_177517 & $\begin{array}{l}15-35 \\
1597-1617\end{array}$ & 56 & 1593 \\
\hline ST6GAL1 & $\begin{array}{l}\text { FW-5TGAAGTACCTCAACCTCGGCA3' } \\
\text { RW-5'GGGAAAGGTGGATCTTGCG3' }\end{array}$ & NM_177517 & $\begin{array}{l}1307-1329 \\
1677-1696\end{array}$ & 58 & 379 \\
\hline
\end{tabular}

T.a. = annealing temperature

to validate the primers. PCR products were verified via an agarose gel run and sequenced using a 3500 Genetic Analyzer (Applied Biosystem, Thermo Fisher Scientific, Waltham, USA) Amplification specificity was verified by using the BLAST tool [65].

\section{QPCR assay}

In gene expression experiments, the suitability of genes to be used as references (RGs) is not given a priori and has to be evaluated each [69]. Preliminary qPCR experiments were performed to optimize the annealing temperature and primer concentration $(100-300 \mathrm{nM})$ of both the target genes and the seven RGs.

The efficiency of PCR amplification for each gene was calculated with a five-point standard curve (1:5 dilution per point) generated on the basis of cDNA samples used as a calibrator. QPCR was conducted using Max SYBR Green/ROX qPCR Master Mix (Thermo Scientific, Thermo Fisher Scientific, Waltham, USA) in a StepOne Plus instrument (Applied Biosystems, Thermo Fisher Scientific, Waltham, USA). Each reaction was run in triplicate and contained $10 \mathrm{ng}$ of cDNA template along

Table 7 Primer sequences, reference sequences, covered regions and positions in the mRNAs, and expected amplicon sizes for both the target and reference genes used in the GPCR analysis

\begin{tabular}{|c|c|c|c|c|}
\hline Gene symbol & Primer sequences & Reference sequence & Covered region / Position & Amplicon, base pairs \\
\hline B4GALT1 & $\begin{array}{l}\text { FW-5'CTGTGTCTCGCCCAAATGCT3' } \\
\text { RW-5'AGGTGAGTGAGTCAAACCATCAG3' }\end{array}$ & HQ700335.1 & $\begin{array}{l}\text { Ex5fw/1011-1030 } \\
\text { Ex6rw/1134-1157 }\end{array}$ & 147 \\
\hline$\angle A L B A$ & $\begin{array}{l}\text { FW-5'GATGACATTGTGTGTGCCAAGA3' } \\
\text { RW-5'AGTGCCACTGATCCAGCTTCTC3' }\end{array}$ & NM_001285635.1 & $\begin{array}{l}\text { Ex3fw/330-351 } \\
\text { Ex4rw/408-429 }\end{array}$ & 100 \\
\hline ST3GAL5 & $\begin{array}{l}\text { FW-5'CCTGAACCAGTTTGATGTCG3' } \\
\text { RW-5'GGTGCACCTTCTGGATAAGTC3' }\end{array}$ & KF055858.2 & $\begin{array}{l}E 4 f w / 655-673 \\
E 5 r w / 745-765\end{array}$ & 111 \\
\hline ST6GAL1 & $\begin{array}{l}\text { FW-5'GAGCTGTGGGACATCATTCAAG3' } \\
\text { RW-5'CACACAGTGACATCATAATGGCAAT3' }\end{array}$ & HQ709167.1 & $\begin{array}{l}E 5 f w / 1065-1086 \\
E 6 r w / 1140-1164\end{array}$ & 100 \\
\hline ATP5B & $\begin{array}{l}\text { FW-5'TTGGACTCCACGTCTCGCATC3' } \\
\text { RW-5'TCCTGGAGGGATTTGTAGTCCTG3' }\end{array}$ & NM_175796.2 & $\begin{array}{l}\text { Ex8fw/1219-1240 } \\
\text { Ex9rw/1304-1326 }\end{array}$ & 108 \\
\hline EIF2B2 & $\begin{array}{l}\text { FW-5'CCGTTCCCATTATGCTCAACTCCAG3' } \\
\text { RW-5'TCCGTTGTCCCTTCCAGTTCCAC3' }\end{array}$ & NM_001015593.1 & $\begin{array}{l}\text { Ex3fw/395-419 } \\
\text { Ex3-4rw/453-475 }\end{array}$ & 81 \\
\hline SDHA & $\begin{array}{l}\text { FW-5'ACGATTACTCCAAGCCCATCCAG3' } \\
\text { RW-5'AACGTAGGAGAGCGTGTGCTTC3' }\end{array}$ & NM_174178.2 & $\begin{array}{l}\text { Ex14fw/1825-1847 } \\
\text { Ex14rw/1883-1904 }\end{array}$ & 80 \\
\hline POLRZA & $\begin{array}{l}\text { FW-5' AATGGAAGCATGTCAATGAGGACTCTC3' } \\
\text { RW-5' CACAGGCAGCACAGTGACGATC3' }\end{array}$ & NM_001206313.1 & $\begin{array}{l}\text { Ex5fw/602-628 } \\
\text { Ex5rw/744-765 }\end{array}$ & 164 \\
\hline$T B P$ & $\begin{array}{l}\text { FW-5'AACAGGTGCTAAAGTCAGAGCAG3' } \\
\text { RW-5' GGAGAACACAGCAGCCATTACG3' }\end{array}$ & NM_001075742.1 & $\begin{array}{l}\text { Ex8fw/1254-1276 } \\
\text { Ex9rw/1334-1355 }\end{array}$ & 102 \\
\hline UXT & $\begin{array}{l}\text { FW-5TGTGGCCCTTGGATATGGTT3' } \\
\text { RW-5'GGTTGTCGCTGAGCTCTGTG3' }\end{array}$ & NM_001037471.2 & $\begin{array}{l}\text { Ex5fw/300-319 } \\
\text { Ex5-6rw/381-400 }\end{array}$ & 101 \\
\hline RPS9 & $\begin{array}{l}\text { FW-5'CCTCGACCAAGAGCTGAAG3' } \\
\text { RW-5'CCTCCAGACCTCACGTTTGTTC3' }\end{array}$ & NM_001101152.1 & $\begin{array}{l}\text { Ex2fw/128-146 } \\
\text { Ex3rw/170-191 }\end{array}$ & 54 \\
\hline
\end{tabular}


with the specific corresponding primer concentrations and $10 \mu \mathrm{l}$ of $2 \mathrm{X}$ master mix in a final reaction volume of $20 \mu \mathrm{l}$. Reverse transcriptase minus (RT-) and no template controls (NTC) were included. The cycling parameters were $95^{\circ}$ for $10 \mathrm{~min}$ to activate the DNA polymerase, followed by 40 cycles of $95^{\circ}$ for $30 \mathrm{~s}$ and T.a. for $1 \mathrm{~min}$. To verify that the primer pairs produced only a single product, a dissociation protocol from $65^{\circ} \mathrm{C}$ to $95^{\circ} \mathrm{C}$ was added after thermocycling.

\section{Oligosaccharide isolation and HPAEC analysis}

OS were isolated from individual colostrum and milk samples as described by Mc Jarrow and Van AmelsfortSchoonbeek [70]. Briefly, after centrifugation at $2000 \times \mathrm{g}$ at $4{ }^{\circ} \mathrm{C}$ for $10 \mathrm{~min}$, the supernatant lipid layer was removed, and the proteins were precipitated by the addition of 0.5 volumes of $1.8 \mathrm{~g} 100 \mathrm{~mL}^{-1} \mathrm{Ba}$ $(\mathrm{OH})_{2} \cdot 8 \mathrm{H}_{2} \mathrm{O}$ and 0.5 volumes of $2 \mathrm{~g} \quad 100 \mathrm{~mL}^{-1}$ $\mathrm{ZnSO}_{4} \cdot 7 \mathrm{H}_{2} \mathrm{O}$. The blend was mixed by vortexing and centrifuged at $12.000 \times \mathrm{g}$ in a microfuge for $10 \mathrm{~min}$ at $4{ }^{\circ} \mathrm{C}$. The supernatant was carefully removed and centrifuged again. The second supernatant was filtered with a nylon filter with a $0.45 \mu \mathrm{m}$ pore size. The total OS fraction was separated using high-performance anionexchange chromatography (HPAEC) in a Dionex PA100 column (Dionex, Sunnyvale, California, USA). The eluted fractions were monitored by pulsed amperometric detection (Dionex ED40), and the gradient was controlled by a Varian Pro Star pump system, which was capable of maintaining a flow rate of $1 \mathrm{ml} / \mathrm{min}$ for the duration of the run. Data were collected and analysed with Star Chromatography Workstation 6.41 (Varian, Inc. Walnut Creek, California, USA), and 6'-SL, 3'-SL, and DSL external standards were used to generate standard curves for comparison.

\section{QPCR data analysis and statistics}

The results obtained with Sequence Detection Software (Applied Biosystems, version 2.1, Thermo Fisher Scientific, Waltham, USA)) were exported as tab-delimited text files and imported into qBase ${ }^{\text {PLUS }}$ software. qBasePLUS included a geNorm ${ }^{\text {PLUS }}$ analysis to screen the optimal set of reference candidate genes [71]. The geNormplus analysis was assessed by using the seven tested candidates and nine samples belonging to four lactation stages. geNorm calculates the gene expression stability measure $(\mathrm{M})$ for a reference gene as the average "pairwise variation" (V) for that gene in relation to all other tested reference genes. Stepwise exclusion of the gene with the highest $M$ value allows the ranking of the tested genes according to their expression stability.

The qBase ${ }^{\text {PLUS }}$ software (version 2.5. Biogazelle, Gent, Belgium) was used to the analyse qPCR data based on the $2^{-\Delta \Delta \mathrm{Ct}}$ method, with implementations to take multiple reference genes and gene-specific amplification efficiencies into account as well as the errors of all measured parameters along the entire calculation track. Moreover, an inter-run calibration algorithm is included to correct for run-to-run differences [72]. Cumulative normalized relative quantities (CNRQs) represent $\mathrm{n}$-fold normalized expression relative to inter-run calibrators (IRC) run across all plates. The logarithm ( $\log )$ of the CNRQs was used for graphical representation and statistical analysis.

Least square (LS) means for the breeds, lactation stages and oligosaccharide contents were calculated with Proc GLM in SAS software (SAS Institute Inc., 2010) using the following model:

$\mathrm{y}_{\mathrm{ijk}}=\mu+\mathrm{C}_{\mathrm{j}}+\mathrm{K}_{\mathrm{i}}+\left(\mathrm{C}_{\mathrm{j}}{ }^{*} \mathrm{~K}_{\mathrm{i}}\right)+\mathrm{e}_{\mathrm{ijk}}$ where:

$\mathrm{y}_{\mathrm{ijk}}=$ phenotype (gene expression or OS content) of the $\mathrm{i}^{\text {th }}$ goat at the $\mathrm{k}^{\text {th }}$ lactation stage in the $\mathrm{j}^{\text {th }}$ breed;

$C_{j}=$ fixed effect of the $j^{\text {th }}$ breed $(j=1-2)$;

$K_{i}=$ fixed effect of the $i^{\text {th }}$ stage of lactation $(i=1-4)$;

$\mathrm{e}_{\mathrm{ijk}}=$ random residual effect.

Pearson correlation coefficients ( $r$ ) for breed, lactation stages and oligosaccharide content were calculated using Proc CORR in SAS software (SAS Institute Inc., 2010).

The significance of the analyses was determined using Tukey's test under the GLM procedure.

\section{Supplementary information}

Supplementary information accompanies this paper at https://doi.org/10. 1186/s12917-019-2206-0.

Additional file 1: Primer concentration, annealing temperatures and standard curve GPCR parameters. Parameters used for the setup of the qPCR experiment for the reference and target genes.

Additional file 2: Results of geNormPlus analysis. The figure represents the most stable reference genes suggested by geNorm for qPCR experiments starting from the right side and moving to the left.

\section{Abbreviations}

3'-SL: 3'sialyllactose; 6'-SL: 6'sialyllactose; GMSCs: Goat milk somatic cells; OS: Oligosaccharides; SOS: Sialyloligosaccharides

\section{Acknowledgements}

We thank Domenico Rufrano, who contributed to the sampling at CREA.

\section{Authors' contributions}

AC conceived the study, carried out the sampling and genetic analysis, and drafted and revised the manuscript; SC managed the animals and processed samples for oligosaccharide analysis; BM supervised the study and contributed to the statistical analysis; CM contributed to the setup of the qPCR protocols, the statistical analysis and manuscript revision. All Authors have read and approved the manuscripts.

\section{Funding}

This research was funded by the Italian Ministry of Agriculture under the framework of the GENZOOT project. The role of the funding body was to support the activities relative to the samples collection, molecular analysis and dissemination.

\section{Availability of data and materials}

Data generated during this study are included in this published article [and its supplementary information files]. cDNA sequences generated during the 
current study are available in the GenBank repository [https://www.ncbi.nlm. nih.gov/genbank/] under accession numbers: HQ700335.1, KF055858.2, HQ709167.1.

\section{Ethics approval and consent to participate}

This study was conducted on the experimental farm of CREA (Consiglio per la Ricerca in Agricoltura e I'Analisi dell'Economia Agraria, Research Centre for Animal Production and Acquaculture, Bella (PZ)), a research institute authorized by the Italian Ministry of Health to use farm animals for experimental purposes (DM 26/96-4). Animal management and care followed the recommendations 408 of European Union directive 86/609/EEC.

\section{Consent for publication}

Not applicable.

\section{Competing interests}

The authors declare that they have no competing interests.

\section{Received: 15 March 2019 Accepted: 4 December 2019}

\section{Published online: 18 December 2019}

\section{References}

1. Bode L. Recent advances on structure, metabolism, and function of human milk oligosaccharides. J Nutr. 2006;136:2127-30.

2. Kunz C, Rudloff $\mathrm{S}$. Health promoting aspects of milk oligosaccharides. Int Dairy J. 2006;16:1341-6.

3. Gnoth MJ, Kunz C, Kinne-Saffran E, Rudloff S. Human milk oligosaccharides are minimally digested in vitro. J Nutr. 2000;130:3014-20.

4. Sakai F, Ikeuchi Y, Urashima T, Fujihara M. Effects of feeding Sialyllactose and Galactosylated N-Acetylneuraminic acid on swimming learning ability and brain lipid composition in adult rats. Components. 2006;254:249-54.

5. Charbonneau MR, O'Donnell D, Blanton LV, Totten SM, Davis JCC, Barratt MJ, et al. Sialylated Milk oligosaccharides promote microbiota-dependent growth in models of infant Undernutrition. Cell. 2016;164:859-71.

6. Ten Bruggencate SJ, Bovee-Oudenhoven IM, Feitsma AL, van Hoffen E, Schoterman $\mathrm{MH}$. Functional role and mechanisms of sialyllactose and other sialylated milk oligosaccharides. Nutr Rev. 2014;72:377-89.

7. Verardo V, Crisá A, Ochando-Pulido JM, Martínez-Férez A. Oligosaccharides From Colostrum and Dairy By-Products: Determination, Enrichment, and Healthy Effects. In: Atta-ur-Rahman, editor. Stud. Nat. Prod. Chem. Amsterdam: Elsevier. 2018. p. 157-178.

8. Kunz C, Rudloff Giessen (Germany). Inst. of Nutritional Science) S (University of $\mathrm{G}$. Health benefits of milk derived carbohydrates. Bull. Int. Dairy Fed. 2002;375:72-9.

9. Gopal PK, Gill HS. Oligosaccharides and glycoconjugates in bovine milk and colostrum. Br J Nutr. 2000;84(Suppl 1):S69-74.

10. Monti L, Cattaneo TMP, Orlandi M, Curadi MC. Capillary electrophoresis of sialylated oligosaccharides in milk from different species. J Chromatogr A. 2015;1409:288-91.

11. Nakamura T, Kawase H, Kimura K, Watanabe Y, Ohtani M, Arai I, et al. Concentrations of sialyloligosaccharides in bovine colostrum and milk during the prepartum and early lactation. J Dairy Sci. 2003;86:1315-20

12. Mcjarrow P, van Amelsfort-Schoonbeek J. Bovine sialyl oligosaccharides : in their season al variations concentrations in milk, and a comparison of the colostrums of Jersey and Friesian cows. Int Dairy J. 2004:571-9.

13. Nakamura T, Urashima T. The milk oligosaccharides of domestic farm animals. Trends Glycosci Glycotechnol. 2004;16:135-42.

14. Martinez-Ferez A, Rudloff S, Guadix A, Henkel C a., Pohlentz G, Boza JJ, et al. Goats' milk as a natural source of lactose-derived oligosaccharides: Isolation by membrane technology. Int Dairy J. 2006;16:173-181.

15. Urashima T, Taufik E, Fukuda K, Asakuma S. Recent advances in studies on Milk oligosaccharides of cows and other domestic farm animals. Biosci Biotechnol Biochem. 2013;77:455-66.

16. Kim HH, Yun SS, Oh CH, Yoon SS. Galactooligosaccharide and sialyllactose content in commercial lactose powders from goat and cow milk. Korean J Food Sci Anim Resour. 2015;35:572-6.

17. Oliveira DL, Wilbey R a., Grandison a. S, Duarte LC, Roseiro LB. separation of oligosaccharides from caprine milk whey, prior to prebiotic evaluation. Int dairy J. Elsevier Ltd; 2012;24:102-106.
18. Martinez-Ferez a, Zapata JE, Guadix a., Almecija MC, Gomez M, Guadix EM. Obtention of goat milk permeates enriched in lactose-derived oligosaccharides. Desalination. 2009;245:730-736.

19. Oliveira DL, Wilbey RA, Grandison AS, Roseiro LB. Natural Caprine whey oligosaccharides separated by membrane technology and profile evaluation by capillary electrophoresis. Food Bioprocess Technol. 2014:915-20.

20. German JB, Schanbacher FL, Lönnerdal B, Medrano JF, McGuire M a., McManaman JL, et al. International milk genomics consortium. Trends Food Sci Technol. 2006;17:656-661.

21. Kim K, Kim S, Min K, Kim C, Lee Y. Genomic structure of human GM3 synthase gene ( $h S T 3 G a l ~ V$ ) and identification of mRNA isoforms in the 50 -untranslated region q. Gene. 2001;273:163-71.

22. García-Vallejo JJ, Gringhuis SI, van Dijk W, van Die I. Gene expression analysis of glycosilation-related genes by real-time polymerase chain reaction. In: Brockhausen I, editor. Glycobiology Protocols. Methods Mol Biol. 2006;347:187-209.

23. Harduin-lepers A. Glycobiology insights comprehensive analysis of sialyltransferases in vertebrate genomes. Glycobiology. 2010:29-61.

24. Harduin-Lepers A, Recchi MA, Delannoy P. 1994, the year of sialyltransferases. Glycobiology. 1995;5:741-58.

25. Harduin-Lepers A, Vallejo-Ruiz V, Krzewinski-Recchi MA, Samyn-petit B, Julien S, Delannoy P. the human sialyltransferase family. Biochimie. 2001;83:727-37.

26. Takashima S, Ishida HK, Inazu T, Ando T, Ishida H, Kiso M, Tsuji S, Tsujimoto M. Molecular cloning and expression of a sixth type of a2,8-sialyltransferase (ST8Sia VI) that sialylates O-glycans. J Biol Chem. 2002;277:24030-8.

27. Asakuma S, Ueda Y, Akiyama F, Uemura Y, Miyaji M, Nakamura M, et al. Short communication: effect of grazing on the concentrations of total sialic acid and hexose in bovine milk. J Dairy Sci. 2010;93:4850-4.

28. Claps S, Di Napoli MA, Caputo AR, Rufrano D, Sepe L, Di Trana A. Factor affecting the $3^{\prime}$ sialyllactose, 6 ' sialyllactose and disialyllactose content in caprine colostrum and milk: breed and parity. Small Rumin Res. 2016;134:8-13.

29. Liu Z, Auldist M, Wright M, Cocks B, Rochfort S. Bovine Milk oligosaccharide contents show remarkable seasonal variation and Intercow variation. J Agric Food Chem. 2017;65:1307-13.

30. Sundekilde UK, Barile D, Meyrand M, Poulsen NA, Larsen LB, Lebrilla CB, German JB, Bertram HC. Natural variability in bovine Milk oligosaccharides from Danish Jersey and Holstein-Friesian breeds. J Agric Food Chem. 2012; 60(24):6188-96

31. Kelly V, Davis S, Berry S, Melis J, Spelman R, Snell R, Lehnert K, Palmer D. Rapid, quantitative analysis of $3^{\prime}$ - and 6' - sialyllactose in milk by flowinjection analysis-mass spectrometry: screening of milks for naturally elevated sialyllactose concentration. J Dairy Sci. 2013;96:7684-91.

32. Claps S, Di Napoli MA, Sepe L, Caputo AR, Rufrano D, Di Trana A, et al. Sialyloligosaccharides content in colostrum and milk of two goat breeds. Small Rumin Res. 2014;121:116-9.

33. Crisà A. Milk carbohydrates and oligosacchharides. In: Park YW, GFW H, editors. Milk dairy products in human nutrition. Chichester: Wiley; 2013. p. 129-47.

34. Barnett AM, Roy NC, McNabb WC, Cookson AL. Effect of a semi-purified oligosaccharide-enriched fraction from caprine milk on barrier integrity and mucin production of co-culture models of the small and large intestinal epithelium. Nutrients. 2016;8.

35. Takashima S, Shuichi T. Unique enzymatic properties of mouse syaliltransferase ST6GALII and ST8SiaVI. Trends Glycosci Glyc. 2004:345-56.

36. Sa B, Benes V, Ja G, Hellemans J, Huggett J, Kubista M, et al. The MIQE guidelines: minimum information for publication of quantitative real-time PCR experiments. Clin Chem. 2009:55:611-22.

37. Wickramasinghe S, Hua S, Rincon G, Islas-Trejo A, German JB, Lebrilla CB, et al. Transcriptome profiling of bovine milk oligosaccharide metabolism genes using RNA-sequencing. PLoS One. 2011;6:e18895.

38. Crisà A, Ferrè F, Chillemi G, Moioli B. RNA-sequencing for profiling goat milk transcriptome in colostrum and mature milk. BMC Vet Res. 2016;12.

39. Datta AK. Comparative sequence analysis in the sialyltransferase protein family: analysis of motifs. Curr Drug Targets. 2009;10:483-98.

40. Audry M, Jeanneau C, Imberty A, Harduin-Lepers A, Delannoy P, Breton C. Current trends in the structure-activity relationships of sialyltransferases. Glycobiology. 2011;21:716-26.

41. Tu L, Banfield DK. Localization of Golgi-resident glycosyltransferases. Cell Mol Life Sci. 2010;67:29-41.

42. Hu H, Eggers K, Chen W, Garshasbi M, Motazacker MM, Wrogemann K, et al. ST3GAL3 mutations impair the development of higher cognitive functions. Am J Hum Genet. 2011;89:407-14. 
43. Mercier D, Wierinckx A, Oulmouden A, Gallet PF, Palcic MM, Harduin-lepers $A$, et al. Molecular cloning, expression and exon / intron organization of the bovine $\beta$-galactoside a2,6 syaliltransferase gene. Glycobiology. 1999:9:851-63.

44. Shi H, Zhu J, Luo J, Cao W, Shi H, Yao D, et al. Genes regulating lipid and protein metabolism are highly expressed in mammary gland of lactating dairy goats. Funct Integr Genomics. 2015;3:309-21.

45. Wickramasinghe S, Rincon G, Islas-Trejo A, Medrano JF. Transcriptional profiling of bovine milk using RNA sequencing. BMC Genomics. 2012;13:45.

46. Paten AM, Duncan EJ, Pain SJ, Peterson SW, Kenyon PR, Blair HT, et al. Functional development of the adult ovine mammary gland-insights from gene expression profiling. BMC Genomics BMC Genomics. 2015;16:748

47. Lemay DG, Ballard OA, Hughes MA, Morrow AL, Horseman ND, La N-R. RNA sequencing of the human milk fat layer transcriptome reveals distinct gene expression profiles at three stages of lactation. PLoS One. 2013;8:e67531.

48. Qasba PK, Ramakrishnan B, Boeggeman E. Structure and function of $\beta-1,4$ galactosyltransferase. Curr Grug Target. 2008;9:292-309.

49. Dalziel M, Huang RY, Dall'Olio F, Morris JR, Taylor-Papadimitriou J, Lau JT. Mouse ST6Gal sialyltransferase gene expression during mammary gland lactation. Glycobiology. 2001;11:407-12.

50. Maksimovic J, Sharp JA, Nicholas KR, Cocks BG, Savin K. Conservation of the ST6Gal i gene and its expression in the mammary gland. Glycobiology. 2011;21:467-81.

51. Capuco AV, Wood DL, Baldwin R, Mcleod K, Paape MJ. Mammary cell number, proliferation, and apoptosis during a bovine lactation: relation to Milk production and effect of bST. J Dairy Sci. 2001;84:2177-87.

52. Stefanon B, Colitti M, Gabai G, Knight CH, Wilde CJ. Mammary apoptosis and lactation persistency in dairy animals. J Dairy Res. 2002;69:37-52.

53. Li P, Rudland PS, Fernig DG, Finch LMB, Wilde CJ. Modulation of mammary development and programmed cell death by the frequency of milk removal in lactating goats. J Physiol. 1999;519:885-900.

54. Mills S, Ross RP, Hill C, Fitzgerald GF, Stanton C. Milk intelligence: mining milk for bioactive substances associated with human health. Int Dairy J. 2011;21:377-401

55. Fuhrer A, Sprenger N, Kurakevich E, Borsig L, Chassard C, Hennet T. Milk sialyllactose influences colitis in mice through selective intestinal bacterial colonization. J Exp Med. 2010;207:2843-54.

56. Martin MJ, Martin-Sosa S, Garcia-Pardo LA, Hueso P. Distribution of bovine milk sialoglycoconjugates during lactation. J Dairy Sci. 2001;84:995-1000.

57. Tao N, DePeters EJ, German JB, Grimm R, Lebrilla CB. Variations in bovine milk oligosaccharides during early and middle lactation stages analyzed by high-performance liquid chromatography-chip/mass spectrometry. J Dairy Sci. 2009;92:2991-3001.

58. Liu Z, Wang T, Pryce JE, MacLeod IM, Hayes B, Chamberlain AJ, Vander Jagt C, Reich CM, Mason BA, Rochfort S, Cocks B. Fine-mapping sequence mutations with a major effect on oligosaccharides content in bovine milk. Sci Reports. 2019:9:2137.

59. Boutinaud $M$, Rulquin $H$, Keisler DH, Djiane J, Jammes $H$. Use of somatic cells from goat milk for dynamic studies of gene expression in the mammary gland. J Anim Sci. 2002;80:1258-69.

60. Cánovas A, Rincón G, Bevilacqua C, Islas-Trejo A, Brenaut P, Hovey RC, et al. Comparison of five different RNA sources to examine the lactating bovine mammary gland transcriptome using RNA-sequencing. Sci Rep. 2014;4:5297.

61. Boutinaud M, Herve L, Lollivier V. Mammary epithelial cells isolated from milk are a valuable, non-invasive source of mammary transcripts. Front Genet. 2015;6:1-12.

62. http://www.primer3.org/

63. Untergasser A, Cutcutache I, Koressaar T, Ye J, Faircloth BC, Remm M, et al Primer3-new capabilities and interfaces. Nucleic Acids Res. 2012:40:1-12.

64. Hall TA. BioEdit: a user friendly biological sequence alignment editor and analysis program for windows 95/98/NT. Nuc Acid Symp Series. 1999:41:95-8.

65. Altschul SF, Madden TL, Schäffer AA, Zhang J, Zhang Z, Miller W, et al. Gapped BLAST and PSI-BLAST:a new generation of protein database search programs. Nucleic Acids Res. 1997;25:3389-402.

66. http://www.ncbi.nlm.gov/BLAST/

67. Ng PC. SIFT: predicting amino acid changes that affect protein function. Nucleic Acids Res. 2003;31:3812-4.

68. Crisà A, De Matteis G, Scatà MC, Moioli B. (2013) analysis of SLC11A1 gene expression in healthy water buffalo (Bubalus bubalis) blood cells by using qPCR. Genet.Mol. Res. 2013;12:6957-67.
69. Hruz T, Wyss M, Docquier M, Pfaffl MW, Masanetz S, Borghi L, et al. RefGenes: identification of reliable and condition specific reference genes for RT-qPCR data normalization. BMC Genomics. 2011;12:156.

70. Mc Jarrow P, Van Amelsfort-Schoonbeek J. Bovine sialyl oligosaccharides: seasonal variations in their concentrations in milk, and a comparison of the colostrums of Jersey and Friesian cows. Int Dairy J. 2004:571-9.

71. Vandesompele J, De Preter K, Pattyn F, Poppe B, Van Roy N, De Paepe A, et al. Accurate normalization of real-time quantitative RT-PCR data by geometric averaging of multiple internal control genes. Genome Biol. 2002; 3:RESEARCH0034.

72. Hellemans J, Mortier G, De Paepe A, Speleman F, Vandesompele J. qBase relative quantification framework and software for management and automated analysis of real-time quantitative PCR data. Genome Biol. 2007:8. R19.

\section{Publisher's Note}

Springer Nature remains neutral with regard to jurisdictional claims in published maps and institutional affiliations.
Ready to submit your research? Choose BMC and benefit from:

- fast, convenient online submission

- thorough peer review by experienced researchers in your field

- rapid publication on acceptance

- support for research data, including large and complex data types

- gold Open Access which fosters wider collaboration and increased citations

- maximum visibility for your research: over $100 \mathrm{M}$ website views per year

At $\mathrm{BMC}$, research is always in progress.

Learn more biomedcentral.com/submissions 